\title{
PENGARUH PENDIDIKAN KESEHATAN TENTANG STIMULASI PERKEMBANGAN ANAK USIA 0-3 TAHUN TERHADAP PENGETAHUAN DAN SIKAP ORANG TUA
}

\section{(The Effect of Health Education of Growing Development Stimulation of Children Aged 0-3 Years to Parents' Knowledge and Attitude)}

\author{
Bagustin Yopy Fatimah Nurwegha*), Bisepta Prayogi ${ }^{* * *}$ \\ STIKes Patria Husada Blitar \\ e-mail : bisepta87@gmail.com
}

\begin{abstract}
Introduction: Human development is the perfect growing of functioning tool that can be passed through the body to grow, mature, and learn. The first 3 years is the important step towards an adult in a child's life. Parents must provide appropriate stimulation to the child's age, therefore parents should have a good knowledge and attitude. The purpose of this study is to analyzed stimulatory effect of health education on the development of children aged 0-3 years knowledge and attitudes towards parents. Method: Research design was one group pre - test and post-test design.Research sample was 35 parets at Posyandu Matahari, Plosorejo Village, Blitar District of Kademangan at May $7^{\text {th }}$ to $14^{\text {th }}$, 2012, its choosed with purposive sampling. The data was collected using questionnaire. Analysis using the Wilcoxon Signed Rank Test with significance $\alpha=0.005$. Results: The result showed enough knowledge on pre-test $(67,7)$ and post-test was good (83.5), while the attitude on the pre-test was good (70.1) and post-test was excellent (86.5) with the level of significance $p=0.001$ on knowledge and attitudes. Discussion: Knowledge and attitudes of the respondents affected increased to better health education. The role of the nurse as an educator in the health service needs to be improved in order to improve knowledge and attitudes.
\end{abstract}

Keywords : health education, knowledge, attitude, development of children aged 0-3 years, the stimulation.

\section{PENDAHULUAN}

Perkembangan adalah bertambah sempurnanya fungsi alat-alat tubuh yang dapat dicapai melalui tumbuh, kematangan maupun belajar (Wong, 2000). Sedangkan menurut Soetjiningsih (1995) perkembangan adalah bertambahnya kemampuan dalam struktur dan fungsi tubuh lebih kompleks dalam pola yang teratur dan dapat diramalkan sebagai hasil dari proses pematangan. Perkembangan anak mencakup perkembangan motorik halus, perkembangan motorik kasar, perkembangan bahasa dan perkembangan perilaku atau adaptasi sosial (Hidayat, 2011). Pada perkembangan terdapat tahapan yang harus dilalui anak untuk menuju dewasa. Tahapan yang terpenting adalah pada masa 3 tahun pertama dalam kehidupan anak, karena merupakan masa yang paling sensitif yang akan sangat menentukan perkembangan otak dan kehidupannya di masa mendatang (Surana, 2001).

Menurut Depkes RI (2006) stimulasi adalah kegiatan merangsang kemampuan dasar anak agar anak tumbuh dan berkembang secara optimal. Setiap anak perlu mendapat stimulasi rutin sedini mungkin dan terusmenerus pada setiap kesempatan. Kurangnya stimulasi dapat menyebabkan penyimpangan perkembangan anak bahkan gangguan yang menetap. Stimulasi perkembangan anak dapat dilakukan oleh ibu dan ayah yang merupakan orang terdekat dengan anak, pengganti atau pengasuh anak, anggota keluarga lain dan kelompok masyarakat di lingkungan rumah 
tangga masing-masing dan dalam kehidupan sehari-hari.

Jumlah balita di Indonesia sekitar $10 \%$ dari seluruh populasi. Maka sebagai calon generasi penerus bangsa, kualitas tumbuh kembang balita di Indonesia perlu mendapat perhatian serius. $16 \%$ balita Indonesia mengalami gangguan perkembangan, baik perkembangan motorik halus dan kasar, gangguan bahasa, kecerdasan kurang dan sosial (Depkes RI, 2006).

Faktor stimulus menjadi sangat penting untuk mengoptimalkan perkembangan anak. Orang tua dapat memberikan stimulasi sejak buah hatinya masih dalam kandungan, saat lahir sampai dia tumbuh besar. Tentu saja dengan intensitas dan bentuk stimulasi yang berbeda-beda pada setiap tahap perkembangannya. Namun hal ini masih sedikit dipahami masyarakat, baik orang tua, kader maupun pemerhati anak (Kurniasih, 2008). Sikap positif dari orang tua dalam stimulasi perkembangan anak sangat berperan besar. Beberapa faktor yang dapat mempengaruhi sikap orang tua diantaranya adalah pengetahuan, pengalaman pribadi, kebudayaan, orang lain, media massa, institusi atau lembaga agama dan emosi yang ada pada diri individu itu sendiri (Sunaryo, 2007).

Berdasarkan hasil penelitian Hariweni (2000) tentang pengetahuan, sikap dan perilaku ibu tentang stimulasi perkembangan anak menunjukkan bahwa pengetahuan ibu tentang stimulasi perkembangan anak masih sangat kurang. Hanya sekitar $1,3 \%$ yang mempunyai pengetahuan tinggi tentang stimulasi; $34,4 \%$ berpengetahuan sedang dan $64,3 \%$ berpengetahuan rendah tentang stimulasi perkembangan anak.

Untuk meningkatkan pengetahuan orang tua dalam stimulasi perkembangan anak dapat dengan memberikan pendidikan kesehatan. Pendidikan kesehatan yaitu serangkaian upaya yang ditujukan untuk menggugah kesadaran, memberikan dan meningkatkan pengetahuan sasaran pendidikan kesehatan yang menyangkut tentang pemeliharaan kesehatan, serta peningkatan kesehatan untuk individu, kelompok, keluarga dan masyarakat (Setiawati, 2008).
Berdasarkan studi pendahuluan yang dilakukan di Desa Plosorejo Kecamatan Kademangan Kabupaten Blitar pada tanggal 24 Februari 2012 jumlah balita adalah 77 anak, yang terdiri dari 44 anak berusia 0-3 tahun dan 33 anak berusia 4-5 tahun. Diantara 8 dari 10 orang tua dengan anak usia 0-3 tahun mengatakan belum mengetahui bagaimana cara dan macam stimulasi perkembangan anak dan mempersepsikan bahwa stimulasi perkembangan anak diberikan dalam pendidikan saat di sekolah. Selain itu stimulasi yang diberikan orang tua tidak sesuai dengan usia anak, dimana seharusnya dalam memberikan stimulasi yang benar harus disesuaikan dengan usia anak.

Berdasarkan latar belakang tersebut di atas maka peneliti tertarik untuk meneliti pengaruh pendidikan kesehatan tentang stimulasi perkembangan anak usia 0-3 tahun terhadap pengetahuan dan sikap orang tua di Posyandu Matahari Desa Plosorejo Kecamatan Kademangan Kabupaten Blitar.

Rumusan masalahnya adalah Bagaimana pengaruh pendidikan kesehatan tentang stimulasi perkembangan anak usia 0-3 tahun terhadap pengetahuan dan sikap orang tua di Posyandu Matahari Desa Plosorejo Kecamatan Kademangan Kabupaten Blitar.

Tujuan umum penelitiannya adalah menganalisis pengaruh pendidikan kesehatan tentang stimulasi perkembangan anak usia 0-3 tahun terhadap pengetahuan dan sikap orang tua di Posyandu Matahari Desa Plosorejo Kecamatan Kademangan Kabupaten Blitar. Sedangkan tujuan khususnya adalah (1) mengidentifikasi pengetahuan dan sikap orang tua tentang stimulasi perkembangan anak usia 0-3 tahun sebelum dilakukan pendidikan kesehatan, (2) mengidentifikasi pengetahuan dan sikap orang tua tentang stimulasi perkembangan anak usia 0-3 tahun sesudah dilakukan pendidikan kesehatan, (3) menganalisis pengaruh pendidikan kesehatan tentang stimulasi perkembangan anak usia 0-3 tahun terhadap pengetahuan dan sikap orang tua.

Manfaat penelitian secara teoritis adalah hasil penelitian ini dapat berguna sebagai bahan pertimbangan profesi keperawatan untuk lebih meningkatkan 
pemahaman peran sebagai pendidik, dan melaksanakan peran sesuai kompetensinya dalam memberikan asuhan keperawatan terhadap stimulasi perkembangan anak usia 0 3 tahun, terutama dalam upaya meningkatkan kualitas perkembangan anak. Manfaat praktis dari penelitian ini adalah Bagi masyarakat luas khususnya orang tua, penelitian ini diharapkan dapat memberikan pengetahuan yang cukup dan menunbuhkan kesadaran diri untuk memberikan sikap yang positif dalam memberikan stimulasi perkembangan pada anak usia 0-3 tahun.

\section{BAHAN dan METODE}

Penelitian ini menggunakan rancangan Pre-eksperiment dan menggunakan desain penelitian One Group Pre-test Posttest design. Yaitu dalam penelitian ini menggunakan hubungan sebab akibat dengan cara penelitian melibatkan satu kelompok subjek dan observasi dilakukan sebanyak dua kali, yaitu sebelum eksperimen dan sesudah eksperimen. Penelirtian ini dilakukan dengan mengobservasi sebelum dan sesudah dilakukan pendidikan kesehatan tentang stimulasi perkembangan anak usia 0-3 tahun. Subyek penelitian ini berjumlah 35 orang tua di Posyandu Matahari Desa Plosorejo Kecamatan Kademangan Kabupaten Blitar yang dipilih dengan teknik purposive sampling yang memiliki anak usia 0-3 tahun dan belum pernah mendapatkan pendidikan

\section{HASIL PENELITIAN}

Karakteristik responden di

Posyandu Matahari Desa Plosorejo

Kecamatan Kademangan Kabupaten Blitar sebanyak 35 responden pada table berikut ini.

Tabel 1 Karakteristik responden di Posyandu Matahari Desa Plosorejo Kecamatan

Kademangan Kabupaten Blitar tanggal 7 Mei 2012-14 Mei 2012

\begin{tabular}{clcc}
\hline No & \multicolumn{1}{c}{ Karakteristik } & Frekuensi & $\%$ \\
\hline $\mathbf{1}$ & Jenis Kelamin & & \\
& Perempuan & 35 & 100 \\
\hline $\mathbf{2}$ & Pendidikan & & \\
& SD & 5 & 14 \\
& SMP & 16 & 46 \\
& SMU & 12 & 34 \\
& PT & 2 & 6 \\
\hline
\end{tabular}

kesehatan tentang stimulasi perkembangan anak.

Variabel yang dinilai adalah adalah pendidikan kesehatan tentang stimulasi perkembangan anak usia dan pengetahuan dan sikap orang tua tentang stimulasi perkembangan anak usia 0-3 tahun.

Alat yang digunakan dalam pengumpulan data adalah (1) Kuesioner untuk mengukur pengetahuan orang tua tentang stimulasi perkembangan anak usia 0-3 tahun sebanyak 15 soal yang meliputi: mengetahui (know) 5 soal, memahami (comprehension) 5 soal, dan analisa (analysis) 5 soal. (2) Kuesioner untuk mengukur sikap orang tua tentang stimulasi perkembangan anak usia 0-3 tahun sebanyak 15 soal yang meliputi: kognitif 5 soal, afektif 5 soal dan konatif 5 soal.

Data yang terkumpul dalam penelitian hasilnya dibandingkan sebelum dan sesudah dilakukan pendidikan kesehatan. Setelah data pengetahuan dan sikap terkumpul maka dilakukan analisis yaitu dengan menjumlahkan jawaban responden pada setiap nomor dan dikalikan $100 \%$ dan hasilnya berupa prosentase (Arikunto, 1998). Dari hasil pengukuran kuesioner pengetahuan dan sikap, data yang terkumpul diolah ntuk mengetahui pengaruh variabel independen dan dependen menggunakan analisis Uji Wilcoxon Signed Rank Test dengan skala data ordinal.

Tabel 1 Karakteristik responden di Posyandu Matahari Desa Plosorejo Kecamatan Kademangan Kabupaten Blitar tanggal 7 Mei 2012-14 Mei 2012

\begin{tabular}{clrc}
\hline No & \multicolumn{1}{c}{ Karakteristik } & Frekuensi & \% \\
\hline $\mathbf{3}$ & Usia & & \\
& 20-29 tahun & 19 & 54 \\
& 30-39 tahun & 15 & 43 \\
& 40-49 tahun & 1 & 3 \\
\hline $\mathbf{4}$ & Pekerjaan & & \\
& PNS & 4 & 12 \\
& Wiraswasta & 12 & 34 \\
& IRT & 19 & 54 \\
\hline $\mathbf{5}$ & Jumlah Anak & & \\
& 1 & 12 & 34 \\
& 2 & 15 & 43 \\
& $>2$ & 8 & 23 \\
\hline
\end{tabular}


Tabel 1 Karakteristik responden di Posyandu Matahari Desa Plosorejo Kecamatan Kademangan Kabupaten Blitar tanggal 7 Mei 2012-14 Mei 2012

\begin{tabular}{llcc}
\hline No & \multicolumn{1}{c}{ Karakteristik } & Frekuensi & $\%$ \\
\hline $\mathbf{6}$ & Informasi stimulasi tumbuh kembang & \\
& Pernah & 31 & 89 \\
& Tidak pernah & 4 & 11 \\
& & & \\
\hline 7 & Sumber informasi & & 29 \\
& TV & 10 & \\
\hline
\end{tabular}

Tabel 1 Karakteristik responden di Posyandu Matahari Desa Plosorejo Kecamatan Kademangan Kabupaten Blitar tanggal 7 Mei 2012-14 Mei 2012

\begin{tabular}{llrc}
\hline No & \multicolumn{1}{c}{ Karakteristik } & Frekuensi & \% \\
\hline & Radio & 1 & 3 \\
& Majalah/Koran & 2 & 6 \\
& Posyandu & 18 & 51 \\
& Tidak Pernah & 4 & 11 \\
\hline
\end{tabular}

Tabel 2 Distribusi rata-rata pengetahuan dan sikap responden pre-test dan post-test di Posyandu Matahari Desa Plosorejo Kecamatan Kademangan Kabupaten Blitar tanggal 7 Mei 2012-14 Mei 2012

\begin{tabular}{lccc}
\hline \multirow{2}{*}{ Variabel } & Pre test & Post test & \multirow{2}{*}{ P Value } \\
\cline { 2 - 3 } & Rata-rata Nilai & Rata-rata Nilai & \\
\hline Pengetahuan & 67,7 & 83,5 & 0,001 \\
Sikap & 70,1 & 86,5 & 0,001 \\
\hline
\end{tabular}

\section{PEMBAHASAN}

Pengetahuan dan sikap orang tua tentang stimulasi perkembangan anak usia $0-3$ tahun sebelum dilakukan pendidikan kesehatan

Pada hasil penelitian didapatkan adanya peningkatan pengetahuan responden dari rata-rata pengetahuan cukup baik (pretest) meningkat menjadi rata-rata pengetahuan baik (post-test) setelah diberikan pendidikan kesehatan, dengan nilai kemaknaan $\mathrm{p}=0,001$. Pada nilai pre-test rata-rata pengetahuan cukup $(67,7)$ sedangkan pada post-test menunjukkan hasil rata-rata pengetauan baik $(83,5)$ dengan kenaikan sebesar 15,8 .

Pengetahuan merupakan hasil dari "tahu" dan ini terjadi setelah seseorang melakukan penginderaan terhadap suatu objek tertentu. Peningkatan pengetahuan dari cukup baik menjadi lebih baik dapat dipengaruhi oleh beberapa faktor diantaranya oleh usia, pendidikan dan informasi. Semakin meningkat usia seseorang maka proses perkembangan mentalnya akan bertambah baik (Notoatmodjo, 2003), hal ini dapat di lihat pada gambar 4.2 yang menunjukkan bahwa usia responden paling banyak berkisar 20-29 tahun (55\%), sehingga pada pre-test rata-rata nilai pengetahuan masih cukup baik. Penelitian ini sejalan dengan penelitian yang dilakukan oleh Wildan (2005) yang menunjukkan bahwa prosentase terbanyak (54\%) usia responden berkisar 20-30 tahun dan terjadi peningkatan tingkat pengetahuan rata-rata 8,46 (pre-test) meningkat menjadi rata-rata 67,31 (post-test).

Pengetahuan dan sikap orang tua tentang stimulasi perkembangan anak usia 0-3 tahun sebelum dilakukan pendidikan kesehatan

Perubahan atau peningkatan pengetahuan responden dalam penelitian ini juga dipengaruhi oleh jumlah anak responden. Hal ini dapat dilihat pada gambar 4.5 yang menunjukkan distribusi anak responden prosentase tebanyak (43\%) responden memiliki 2 anak sehingga responden sudah memiliki pengalam dan pengetahuan responden sudah cukup baik pada pre-test.

Pengetahuan baik dapat juga di pengaruhi oleh tingkat pendidikan. Pada umumnya semakin tinggi tingkat pendidikan seseorang maka akan semakin baik pula pengetahuannya (Notoatmodjo, 2003). Hal ini dapat di lihat pada gambar 4.3 yang menunjukkan bahwa paling banyak responden berpendidikan SMP (46\%), dan rata-rata pengetahuan responden pada pre-test dalam kriteria cukup baik.

Selain itu peningkatan pengetahuan juga dapat dipengaruhi oleh informasi. Informasi akan memberikan pengaruh pada pengetahuan seseorang meskipun orang tersebut mempunyai tingkat pendidikan yang 
rendah. Tetapi jika seseorang tersebut mendapat informasi yang baik dari berbagai media maka hal itu akan dapat meningkatkan pengetahuan seseorang (Notoatmodjo, 2003). Hal ini dapat dilihat pada gambar 4.7 yang menunjukkan bahwa media informasi responden paling banyak adalah dari Posyandu sebesar (57\%), dan di Posyandu Matahari ini aktif dalam memberikan pendidikan kesehatan, sehingga hanya beberapa responden saja yang memiliki pengetahuan tidak baik. Dengan cara bimbingan atau penyuluhan, kontak antara klien dengan petugas pendidikan kesehatan lebih intensif, dan setiap masalah yang dihadapi oleh klien dapat langsung dibantu penyelesaiannya (Notoadmodjo, 2003).

Menurut Setiawati (2008), pendidikan kesehatan merupakan serangkaian upaya yang ditujukan untuk menggugah kesadaran, memberikan dan meningkatkan pengetahuan sasaran pendidikan kesehatan yang menyangkut tentang pemeliharaan kesehatan serta peningkatan kesehatan baik untuk individu, keluarga, kelompok maupun masyarakat. Pendidikan kesehatan tentang stimulasi perkembangan anak usia 0-3 tahun dimaksudkan untuk memberikan pengetahuan pada orang tua sehingga terjadi peningkatan pengetahuan yang lebih baik. Pengetahuan dapat diperoleh diantaranya melalui informasi dalam hal ini adalah pendidikan kesehatan.

Pendidikan kesehatan yang dilakukan oleh peneliti menggunakan metode pendidikan kelompok (saat Posyandu), peneliti memberikan materi menggunakan LCD dan memberikan booklet yang disertai cara dan gambar-gambar kepada masing-masing responden, selain itu juga memberikan beberapa simulasi dan memberikan evaluasi langsung setelah diberikan pendidikan kesehatan. Sehingga orang tua dapat melihat secara langsung bagaimana cara yang benar dalam memberikan stimulasi perkembangan anak usia 0-3 tahun kepada anaknya dan mengevaluasi penerimaan materi yang telah disampaikan.

\section{Pengaruh pendidikan kesehatan tentang stimulasi perkembangan anak usia 0-3 tahun terhadap pengetahuan dan sikap orang tua}

Pendidikan kesehatan ini memberikan kesempatan pada orang tua untuk lebih memahami tentang Stimulasi Perkembangan
Anak Usia 0-3 Tahun, sehingga pengetahuan orang tua dapat meningkat menjadi lebih baik.

Pada variabel sikap dalam penelitian ini didapatkan adanya peningkatan sikap responden dari rata-rata baik $(70,1)$ pada pretest meningkat menjadi rata-rata sangat baik $(86,5)$ pada post-test, dengan peningkatan sebesar 16,4 dan tingkat kemaknaan $\mathrm{p}=0,001$ yang berarti ada pengaruh pendidikan kesehatan tentang stimulasi perkembangan anak uusia 0-3 tahun terhadap sikap orang tua.

Faktor-faktor yang mempengaruhi pembentukan atau perubahan sikap diantaranya adalah pengetahuan atau pengalaman pribadi, media informasi dan emosi yang ada pada diri individu itu sendiri (Saifuddin, 2011). Pengetahuan/pengalaman pribadi akan membentuk dan mempengaruhi penghayatan seseorang terhadap stimulus atau objek. Tanggapan terhadap stimulasi perkembangan anak usia 0-3 tahun, akan menjadi salah satu dasar pembentukan sikap. Untuk dapat mempunyai tanggapan dan penghayatan, seseorang harus mempunyai pengalaman yang berkaitan dengan stimulus atau objek tersebut (Saifuddin, 2011). Hal ini dapat dilihat pada gambar 4.8 yang menunjukkan rata-rata pengetahuan responden adalah cukup $(67,7)$ pada pre-test dan setelah mendapat pengetahuan (Pendidikan Kesehatan) meningkat menjadi rata-rata baik $(83,5)$ pada post-test. Sedangkan pada gambar 4.9 menunjukkan rata-rata nilai sikap baik $(70,1)$ pada pre-test, setelah mendapatkan pendidikan kesehatan rata-rata nilai sikap meningkat menjadi sangat baik $(86,5)$ pada post test. Penelitian ini juga diperkuat oleh penelitian sebelumnya (Wildan, 2005). Hasil penelitian menunjukkan bahwa rata-rata pengetahuan 8,46 dan rata-rata sikap 40,62 (pre-test), kemudian setelah diberikan pendidikan kesehatan meningkat menjadi ratarata pengetahuan 67,31 dan rata-rata sikap 69,69 (post-test).

Perubahan/peningkatan sikap juga dapat dipengaruhi oleh media massa (sumber informasi). Media massa sebagai sarana komunikasi yang memberi pengaruh terhadap pembentukan opini seseorang, walaupun pengaruh media massa tidak sebesar pengaruh interaksi secara langsung namun dalam proses pembentukan dan perubahan sikap peranan media massa tidak kecil artinya (Saifuddin, 2011). Hal ini dapat dilihat pada gambar 4.7 yang menunjukkan bahwa paling banyak 
responden mendapat informasi dari Posyandu (57\%). Hasil penelitian ini juga diperkuat oleh penelitian Sutanti (2010) yang menunjukkan bahwa $65 \%$ responden yang sudah mendapatkan informasi sikapnya meningkat dari negatif menjadi positif.

Perubahan sikap juga dipengaruhi oleh faktor emosi yang ada pada diri individu itu sendiri. Tidak semua bentuk sikap dientukan oleh situasi lingkungan dan pengalaman pribadi seseorang. (Saifuddin, 2011). Hal ini terlihat dari hasil kuesioner pada item pertanyaan "menurut saya untuk meningkatan kemampuan dasar anak dapat dengan memberikan stimulasi perkembangan anak" menunjukkan bahwa responden sangat setuju terhadap Stimulasi Perkembangan Anak Usia 0-3 Tahun.

Menurut Notoatmodjo (2003) sikap merupakan reaksi atau respon seseorang terhadap suatu stimulus atau objek tertentu. Sikap mempunyai beberapa komponen diantaranya adalah pengetahuan (kognitif), perasaan (afektif) dan perilaku (konatif). Sikap juga mempunyai tingkatan yaitu mulai dari menerima (receiving), merespon (responding), dan menghargai (valuing).

Pendidikan kesehatan tentang Stimulasi Perkembangan Anak Usia 0-3 Tahun merupakan salah satu upaya untuk meningkatkan pengetahuan yang merupakan salah satu komponen dari sikap. Dengan pengetahuan yang baik maka orang tua (responden) akan bersikap ke arah yang lebih baik atau positif terhadap perkembangan anaknya. Dari sikap yang positif kemungkinan orang tua untuk berperilaku baik terhadap stimulasi perkembangan anak sangat mungkin, dikarenakan sebagaian besar responden adalah ibu rumah tangga

\section{SIMPULAN dan SARAN SIMPULAN}

Tingkat pengetahuan responden rata-rata cukup $(67,7)$ dan tingkat sikap responden ratarata baik $(70,1)$ sebelum diberikan pendidikan kesehatan, tingkat pengetahuan responden meningkat menjadi baik $(83,5)$ dan tingkat sikap responden rata-rata meningkat menjadi sangat baik $(86,5)$ setelah diberikan pendidikan kesehatan, berdasarkan analisis Wilcoxon Signed Rank Test ada pengaruh pendidikan kesehatan tentang stimulasi perkembangan anak usia 0-3 tahun terhadap pengetahuan dan sikap orang tua dengan kenaikan rata-rata pengetauan sebesar 15,8 dan kenaikan rata-rata sikap sebesar 16,4, dengan tingkat kemaknaan masing-masing $\mathrm{p}=0,001$.

\section{SARAN}

Saran bagi perawat memberikan penyuluhan dan pelatihan kepada kader Posyandu cara melakukan stimulasi perkembangan anak yang tepat kepada orang tua di Posyandu, sehingga diharapkan nantinya kader dapat mengajarkan kepada orang tua untuk melakukan stimulasi perkembangan anak yang tepat dan perkembangan anak akan optimal, bagi kader Posyandu dapat mengajarkan kepada orang tua bagaimana cara-cara yang tepat dalam melakukan stimulasi perkembangan anak. APE (Alat Permainan Edukatif) yang ada sebaiknya digunakan atau dimanfaatkan guna memberikan pelatihan kepada orang tua. Sehingga orang tua dapat melihat secara langsung bagaimana cara yang tepat dan benar dalam memberikan stimulasi perkembangan anak. Sedangkan bagi mahasiswa Keperawatan dapat melaksanakan pengabdian kepada masyarakat dengan memberikan pendidikan kesehatan, pelatihan dan mengajarkan baik kepada kader posyandu maupun orang tua bagaimana cara yang tepat dalam melakukan stimulasi perkembangan anak.

\section{REFERENSI}

Abu, A 2002, Psikologi Sosial, Rineka Cipta, Jakarta.

Depkes RI 2006, Pedoman Pelaksanaan Stimulasi Deteksi dan Interveni Dini Tumbuh Kembang Anak di Tingkat Pelayanan Kesehatan Dasar.

Hariweni, T 2003, 'Pengetahuan Sikap dan Perilaku Ibu Bekerja dan Tidak Bekerja tentang Stimulasi pada Anak balita', Skripsi, Universitas Sumatra Utara, Medan.

Hidayat, AA 2008, Ilmu Kesehatan Anak untuk Pendidikan Kebidanan, Salemba Medika, Jakarta. 
Hidayat, AA 2009, Metode Penelitian Keperawatandan Tehnik Analisa Data, Salemba Medika, Jakarta.

Hutagulung, I 2007, Pengembangan Kepribadian, PT Indeks, Jakarta.

Saifuddin, A 2011, Sikap Manusia Teori dan Pengukurannya, Pustaka Pelajar, Yogyakarta.

Sunaryo 2007, Psikologi untuk Keperawatan, EGC, Jakarta.

Sutanti, IT 2010, 'Pengaruh Penyuluhan Kesehatan tentang Menstruasi terhadap Sikap Remaja putrid di MTs. Ma'arif Kelurahan srengat Kecamatan Srengat Kabupaten Blitar', Karya Tulis Ilmiah, STIKes Patria Husada Blitar, Blitar.

Setiawati, S Pendidikan Kesehatan, Trans Info Media, Jakarta.

Notoadmodjo, S 2003, Ilmu Kesehatan Masyarkat, Rineka Cipta, Jakarta.
Notoatmodjo, S 2003, Pendidikan dan Perilaku Kesehatan, Rineka Cipta, Jakarta.

Soetjiningsih 1995, Tumbuh Kembang Anak, EGC, Jakarta.

Taufan, S 2001, Perkembangan Motorik Halus Kasar, diakses pada 4 Maret 2012, <http://www.balitaanda.indoglobal.com/B alita271perkembang anmotorik_haluskasar.html>.

Depkes RI 2006, Tumbuh kemban anak, diakses pada 4 Maret 2012, $<$ http://www.depkes.co.id/perkembangananak>.

Wildan 2005, 'Pengaruh Penyuluhan PreOperasi terhadap Pelaksanaan Mobilisasi Post-Operasi pada Pasien Pembedahan', Universitas Airlangga, Surabaya. 